EETP Vol. 16, 2021, №. 2(60)

ISSN 1896-2327 / e-ISSN 2353-7787

DOI: 10.35765/eetp.2021.1660.01

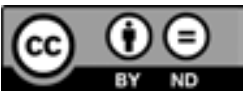

Nadesłano: 8.01.2021

Zaakceptowano: 8.02.2021

Sugerowane cytowanie: Bocharova 0. (2021). Przygotowanie do zawodu przyszłych nauczycieli edukacji wczesnoszkolnej na Ukrainie „Edukacja Elementarna w Teorii i Praktyce", vol. 16, nr 2(60), s. 9-23. D0I: 10.35765/eetp.2021.1660.01

\title{
Przygotowanie do zawodu przyszłych nauczycieli edukacji wczesnoszkolnej na Ukrainie
}

\section{Preparation for the Profession of Early School Teachers in Ukraine}

\author{
SŁOWA KLUCZE ABSTRAKT \\ edukacja wczesno- \\ W niniejszym artykule podejmowany jest problem przygotowania \\ szkolna, reforma, \\ studentów do zawodu nauczyciela edukacji wczesnoszkolnej na Ukra- \\ nauczyciel, przygoto- \\ inie. Analiza retrospektywna literatury wskazuje, że po raz pierwszy \\ wanie zawodowe \\ problem przygotowania nauczycieli do zawodu stał się przedmiotem \\ dyskusji dopiero w XVIII wieku. Od tego czasu nastąpiły istotne zmia- \\ ny w organizacji procesu kształcenia nauczycieli do zawodu. W 2018 \\ roku w szkolnictwie ukraińskim została wypracowana i wprowadzona \\ koncepcja „Nowa ukraińska szkoła”. Głównym jej zadaniem była re- \\ forma struktury szkolnictwa, a przede wszystkim edukacji wczesno- \\ szkolnej. W tym celu wypracowano standard kształcenia przygotowu- \\ jący do wykonywania zawodu nauczyciela edukacji wczesnoszkolnej \\ „Nauczyciel klas początkowych w szkole ogólnodostępnej”. W pierw- \\ szej części opracowania zostało zaprezentowanych pięć etapów po- \\ wstania i rozwoju organizacyjnego szkół pedagogicznych przygoto- \\ wujących przyszłych nauczycieli edukacji wczesnoszkolnej do zawodu \\ (koniec XVIII i początek XXI wieku). Druga część poświęcona zosta- \\ ła organizacji procesu nauczania przyszłych nauczycieli klas początko- \\ wych w Akademii Humanistyczno-Pedagogicznej w Chmielnickim.
}




\section{KEYWORDS ABSTRACT}

early education, The issue of training students for the profession of early education school, reform, teachers in Ukraine is considered in the article. Retrospective analysis teacher, professional of literature shows that the question of preparing teachers for their job training was first discussed in the 18 th century. Since then, there have been significant changes in the organization of teachers' preparation for the profession. In 2018, the concept of a "New Ukrainian School" was developed and implemented into Ukrainian education. Its main task was to reform the education system, especially early school education. For this purpose, the standard of educating early school teachers was prepared. It is entitled: "Early Education Teacher in the Public School". In the first part of this article, the author presents five stages of the emergence and organizational development of educational institutions which train future teachers to work in primary schools (from the end of the 18th to the beginning of the 21 st century). The second part focuses on organizing the process of educating future early school teachers in the Khmelnytsky Humanities and Pedagogic Academy.

\section{Wprowadzenie}

Przygotowanie zawodowe przyszłych nauczycieli edukacji wczesnoszkolnej jest przedmiotem badań zarówno naukowców ukraińskich, jak i zagranicznych. W społeczeństwie ukraińskim zawód nauczyciela jest bardzo rozpowszechniony. Od momentu odzyskania przez Ukrainę niepodległości (1991), w roku szkolnym 1991/1992 liczba nauczycieli szkół ogólnodostępnych wynosiła 543 tys. osób, zaś na początku roku szkolnego 2017/2018 blisko 437 tys. osób. Wśród nich 54,5\% nauczycieli pracowało w mieście, a 45,5\% na wsi.

W roku szkolnym 1991/1992 do szkół uczęszczało 7,102 mln uczniów, podczas gdy w 2016/2017 ta liczba wynosiła już 3,846 mln osób. W ciągu dwudziestu pięciu lat niemal o połowę zmniejszyła się liczba uczniów. Jeśli w roku 1991/1992 na jednego nauczyciela przypadało 15 uczniów, to w roku 2017/2018 ta liczba wynosiła 8 uczniów (Oswita w cyfrach: jak zminylas kilkist szkil za ostanni roky 2017).

W roku 2016/2017 w edukacji wczesnoszkolnej pracowało 92664 osób. Większość z nich (84,3\% - 78 151osób) posiadała wyższe wykształcenie (tytuł zawodowy - magister), a 13\% (12 068 osób) stanowili nauczyciele po ukończeniu kolegium/liceum pedagogicznego (tytuł zawodowy - młodszy specjalista). Staż pracy nauczyciela edukacji wczesnoszkolnej wynosił: do 3 lat (6922 osoby), od 3 do 10 (10 393); od 10 do 20 lat (16 297), więcej niż 20 lat (59 052) (Skilky wczyteliw narachuwaly mynulogo nawczalnogo roku? 2017). 
Od dłuższego już czasu szkoła nie odpowiadała na wyzwania i zachodzące w świecie przemiany. Problemy związane z niedostosowaniem bazy materialnej szkół do potrzeb społecznych oraz starzeniem się kadry nauczycielskiej negatywnie odbijały się na wizerunku szkoły. Oprócz tego edukacja wczesnoszkolna bardzo często była krytykowana przez rodziców. W ich opinii szkoła nie zachęcała uczniów do nauki i rozwoju kreatywnego myślenia. Dodatkowo, wielu pierwszoklasistów miało problemy $\mathrm{z}$ adaptacją $\mathrm{w}$ szkole, której towarzyszyło negatywne nastawienie rodziców do organizacji procesu edukacyjnego w szkole. Ta sytuacja doprowadziła do kryzysu w przygotowaniu zawodowym nauczycieli, ponieważ tylko osoba o wysokim poziomie wiedzy i umiejętności może odpowiednio reagować na zmiany współczesnego świata. Dlatego przed szkolnictwem wyższym stało trudne zadanie - zmienić podejście do przygotowania zawodowego przyszłych nauczycieli.

W „Narodowej Strategii Rozwoju Edukacji na Ukrainie do 2021 r.” (2013) zostało zapisane, że przygotowanie przyszłych nauczycieli jest priorytetowym zadaniem polityki edukacyjnej państwa (Pro Nacionalnu strategiju rozwytku oswity w Ukrajini na period do 2021 roku 2013). W tym celu został wypracowany i wprowadzony standard kształcenia przygotowujący do wykonywania zawodu nauczyciela edukacji wczesnoszkolnej „Nauczyciel klas początkowych w szkole ogólnodostępnej” (Stanadart „Wczytel poczatkowych klasiw zaktadu zagalnoji serednoji oswity 2018), a także zostały zmodyfikowane programy nauczania oraz ustalone nowe zasady i kryteria oceniania osiągnięć uczniów. Głównym celem działalności nauczyciela edukacji wczesnoszkolnej była organizacja nauczania, wychowania i rozwoju uczniów oraz kształtowanie umiejętności niezbędnych dla rozwoju zdolności intelektualnych, twórczych i fizycznych uczniów.

W niniejszym opracowaniu postaram się przybliżyć problem przygotowania do zawodu nauczyciela edukacji wczesnoszkolnej na Ukrainie.

\section{Przygotowanie zawodowe - ujęcie definicyjne}

W Wielkim Stowniku Języka Ukraińskiego (red. Busel 2004: 767) pojęcie „przygotowanie" traktuje się jako zasób wiedzy, umiejętności oraz doświadczenia, które człowiek zdobywa, uczestnicząc w procesie kształcenia oraz działalności praktycznej; zasób wiedzy, nabyty przez jakąkolwiek osobę (Ożegów, Szwedowa 1990: 532); nabywanie doświadczenia społecznego w celu późniejszego go zastosowania w wykonywanej pracy (Onuszkin, Ogarew 1995: 132).

Jednym z rodzajów przygotowania jest przygotowanie zawodowe. W Encyklopedii Pedagogicznej (red. Kairow, Pietrow 1964-1968: 549) pojęcie „przygotowanie zawodowe" oznacza proces przygotowania specjalisty dla jednej z branż, czyli proces związany ze zdobywaniem pewnego zawodu. W literaturze psychologiczno-pedagogicznej 
istnieje kilka podejść do określenia treści pojęcia „przygotowanie zawodowe”. Psycholodzy rozpatrują je jako zasób zwiększenia potencjału indywidualnego człowieka, rozwoju jego sił, aktywności poznawczej i twórczej na podstawie przyswajania wiedzy ogólnonaukowej i fachowej oraz nabywania umiejętności. Według pedagogów pojęcie "przygotowanie zawodowe” oznacza uzyskanie zawodu, co jest wynikiem zdobywania kwalifikacji i umiejętności zawodowych oraz kształtowania cech niezbędnych dla podjęcia pracy w zawodzie (Szkwir 2018: 110).

Walentyna Semiczenko (Semiczenko 1992, za: Szkwir 2018: 110) termin „przygotowanie zawodowe" rozpatruje w trzech aspektach: jako proces, podczas którego odbywa się wszechstronne przygotowanie specjalistów; jako cel i wynik działalności uczelni, oraz jako włączenie studenta w działalność dydaktyczno-wychowawczą. Zdaniem Swietlany Sysojewej i Iriny Sokołowej (Sysojewa, Sokołowa 2010: 133), przygotowanie zawodowe „to jednolity system z dużą ilością związanych ze sobą komponentów (elementów, podsystemów), które charakteryzują się kompleksowością, hierarchicznością, związkami wewnętrznymi i zewnętrznymi. Przygotowanie zawodowe jest procesem stałym, skierowanym na zdobywanie doświadczenia w zawodzie, który pozwala spostrzegać rzeczywistość uwzględniając współczesne wymogi rynku pracy".

W ukraińskiej Ustawie o szkolnictwie wyższym (Zakon Ukrajiny „Pro wyszczu oswitu" 2014) jest zapisane, że przygotowanie zawodowe to uzyskiwanie kwalifikacji oraz uprawnień zawodowych nabytych podczas studiów. Przygotowanie zawodowe kończy się uzyskaniem tytułu zawodowego (Zakon Ukrajiny „Pro wyszczu oswitu” 2014). W Koncepcji rozwoju wykształcenia pedagogicznego (Koncepcija rozwytku pedagogicznoji oswity 2018) znajdziemy zapis: „kwalifikacje zawodowe pracownika pedagogicznego to całokształt zdobytych kompetencji, potwierdzony odpowiednim dokumentem (dyplomem), który daje możliwość prowadzenia działalności pedagogicznej”.

\section{Geneza szkól pedagogicznych przygotowujących przyszłych nauczycieli edukacji wczesnoszkolnej do zawodu i ich rozwój organizacyjny (koniec XVIII wiekU do początku XXI wieku)}

Na gruncie ukraińskim przygotowanie do zawodu nauczyciela sięga swoimi korzeniami do początków XVIII wieku. Oksana Szkwir w monografii Stopniowe przygotowanie przysztych nauczycieli edukacji wczesnoszkolnej do prowadzenia badań pedagogicznych (Stupenewa pidgotowka majbutnich uczyteliw pocztakowoji szkoly do prowedennja pedagogicznych doslidżen) wyodrębniła cztery etapy powstania i rozwoju 
organizacyjnego szkół pedagogicznych przygotowujących przyszłych nauczycieli edukacji wczesnoszkolnej do zawodu (Szkwir 2018: 45).

\section{Pierwszy etap (ideowo-organizacyjny) - od końca XVIII do początku XX wieku}

Ten etap charakteryzuje się powstaniem pierwszych szkół nauczycielskich. Na początku XIX wieku wybitny rosyjski pedagog Konstantyn Uszyński (1824-1870) w artykule Projekt seminarium nauczycielskiego opisał dwa typy szkół przygotowujących do zawodu nauczyciela. Były to: Przygotowawcze Szkoły Nauczycielskie (od 3 do 4 lat) (dalej - Szkoła) oraz Seminaria Nauczycielskie (od 2 do 4 lat) (dalej-Seminarium). Celem Szkoły było przekazywanie kandydatom wiedzy teoretycznej oraz rozpoznawanie i rozwijanie zdolności pedagogicznych. Nauka kończyła się egzaminem nauczycielskim. Absolwent, który po ukończeniu szkoły składał egzamin i uzyskiwał pozytywną opinię komisji, mógł kontynuować studia w Seminarium. Po jego ukończeniu odbywał roczny staż pedagogiczny, a po uzyskaniu pozytywnej oceny mógł pracować w zawodzie (w szkole parafialnej) (Uszyński 1983: 42). Z czasem pedagodzy i działacze oświatowi zaczęli głosić potrzebę kształcenia nauczycieli na poziomie wyższym. W 1872 roku powstały pierwsze Instytuty Pedagogiczne w Moskwie, Petersburgu oraz Tyflisie. Czas nauki w nich trwał trzy lata. Na początku XX wieku ich liczba znacznie się zwiększyła. Jeśli na początku 1907 roku w Imperium Rosyjskim istniało 7 Instytutów Pedagogicznych, to w 1917 roku ich liczba wynosiła 58, w tym 11 na Ukrainie. Równocześnie działały 33 Seminaria Nauczycielskie (Szkwir 2018: 45).

\section{Drugi etap (początkowy) - lata 1917-1990}

Po Rewolucji Październikowej (1917) nastąpiły duże zmiany w systemie przygotowania nauczycieli. Społeczeństwo potrzebowało nowej kadry pedagogicznej, w tym dla edukacji wczesnoszkolnej. W 1917 roku Centralna Rada Ukraińskiej Republiki Ludowej uchwaliła ustawę, zgodnie z którą Seminaria Nauczycielskie zostały zlikwidowane i na ich miejscu powstały Średnie Szkoły Pedagogiczne z czteroletnim programem nauczania. Jednak ten typ szkół istniał niedługo. W latach 1921-1922, w celu podniesienia jakości kształcenia nauczycieli, zostały one przekształcone w Wyższe Kursy Pedagogiczne. Czas nauki w nich trwał 3 lata. Głównym zadaniem było przygotowanie nauczycieli do zawodu w szkołach wiejskich. Jednak Wyższe Kursy Pedagogiczne czekał ten sam los co i Średnie Szkoły Pedagogiczne. W 1925 roku zostały one przekształcone w Technika Pedagogiczne. W 1937 roku Technika Pedagogiczne zostały zastąpione przez tzw. Seminaria Pedagogiczne.

W drugiej połowie lat 50. XX wieku absolwent po ukończeniu Seminarium Pedagogicznego miał dwie specjalności - podstawową (nauczyciel klasy I-IV) i dodatkową 
(nauczyciel matematyki lub języka ukraińskiego w klasach V-VIII) (Chomicz 1999, za: Szkwir 2018: 47). Koniec lat 50. i początek lat 60. XX wieku charakteryzowały się stałym podnoszeniem jakości kształcenia nauczycieli edukacji wczesnoszkolnej oraz powstawaniem nowych wydziałów w Instytutach Pedagogicznych.

W latach 80-90. XX wieku wymogi do przygotowania przyszłych nauczycieli do zawodu zostały znacznie podwyższone. Poszukiwanie nowych i efektywnych rozwiązań dla przygotowania nauczycieli edukacji wczesnoszkolnej miało miejsce w zespołach badawczych na uczelniach oraz w gronie praktyków. Wymiana doświadczeń w zakresie pracy w szkole odbywała się między nauczycielami i naukowcami na łamach czasopism „Ridna szkoła” („РіАна школа”), „Sowietskaja pedagogika” („Советская педагогика”) i „Wospitanie szkolnikow” („Воспитание школьников”). Podstawowymi typami szkół, w których w tym czasie przygotowywano nauczycieli edukacji wczesnoszkolnej do zawodu, były - Licea/Seminaria Pedagogiczne oraz Instytuty Pedagogiczne. Po ukończeniu Seminarium/Liceum Pedagogicznego absolwent zdobywał wykształcenie średnie, a po zakończeniu Instytutu Pedagogicznego - wykształcenie wyższe (Chomicz 1999, za: Szkwir 2018: 49-50).

\section{Trzeci etap (czterostopniowy) - lata 1991-2013}

Radykalne zmiany w kwestii kształcenia nauczycieli edukacji wczesnoszkolnej wprowadziło wejście w życie Ustawy o edukacji (1991) (Zakon Ukrajiny „Pro oswitu” 1991). Zgodnie z ustawą absolwent po zakończeniu Liceum/Seminarium Pedagogicznego zdobywał tytuł zawodowy młodszego specjalisty, po zakończeniu uczelni wyższej licencjata (bakaławra), specjalisty lub magistra. W opinii ukraińskiego badacza Mikołaja Ewtucha:

W latach 1995-2005 nastąpiły duże zmiany w systemie przygotowania przyszłych nauczycieli. Po pierwsze, odbyła się optymalizacja typów szkół pedagogicznych, niektóre licea, kolegia (I-II poziom akredytowania) weszły w struktury Instytutów, Akademii lub Uniwersytetów. Po drugie, w tym okresie ponad trzykrotnie zwiększyła się liczba studentów w szkolnictwie wyższym. Po trzecie, zgodnie z zaleceniem Ministerstwa Edukacji i Nauki Ukrainy przy uniwersytetach zostały stworzone tzw. Kompleksy Pedagogiczne (dalej - Kompleks) „uczeń - student - młodszy specjalista - licencjat - specjalista - magister" (Ewtuch 2005: 6).

Jednym z pierwszych uniwersytetów na Ukrainie, w którym w 1994 roku został utworzony Piwdennoukraiński Kompleks Edukacyjny „Pedagog”, był Piwdennoukraiński Państwowy Uniwersytet Pedagogiczny im. Konstantyna Uszyńskiego (https:// pdpu.edu.ua/). W jego skład wchodziły: 2 przedszkola, 10 szkół ogólnodostępnych, 5 Kolegiów Pedagogicznych oraz Centrum Rozwoju Dziecka „Młoda Gwardia”. Powstanie tego Kompleksu dało możliwość stworzenia miejsc realizacji studenckich 
praktyk pedagogicznych, co podnosiło jakość kształcenia. Przygotowanie przyszłych nauczycieli do zawodu odbywało się według programów studiów eksperymentalnych.

W Tab. 1. została przedstawiona struktura przygotowania przyszłych nauczycieli edukacji wczesnoszkolnej w latach 1991-2013.

Tabela 1. Struktura przygotowania przyszłych nauczycieli edukacji wczesnoszkolnej w latach $1991-2013$

\begin{tabular}{|c|c|c|c|}
\hline Tytul zawodowy & $\begin{array}{c}\text { Typ uczelni } \\
\text { (poziom akredytowania) }\end{array}$ & $\begin{array}{l}\text { Typ ukończonej } \\
\text { szkoły (klasy) }\end{array}$ & $\begin{array}{c}\text { Czas trwania } \\
\text { nauki }\end{array}$ \\
\hline Młodszy specjalista & $\begin{array}{l}\text { kolegium/liceum } \\
\text { pedagogiczne } \\
\left(\mathrm{I}-\mathrm{II} \text { poz. akred }{ }^{1}\right)\end{array}$ & $\begin{array}{l}\text { po ukończeniu } \\
\text { klasy IX }\end{array}$ & 4 lata \\
\hline Licencjat & $\begin{array}{c}\text { szkoła wyższa } \\
\left(\mathrm{III}^{2}-\mathrm{IV}^{3} \text { poz. akred.): }\right.\end{array}$ & $\begin{array}{l}\text { po ukończeniu } \\
\text { kolegium/liceum } \\
\text { pedagogicznego }\end{array}$ & $1-2$ lata \\
\hline Licencjat & $\begin{array}{c}\text { szkoła wyższa } \\
\text { (III-IV poz. akred.); }\end{array}$ & $\begin{array}{c}\text { po ukończeniu szkoły } \\
\text { ogólnodostępnej } \\
\text { (klasa XI) }\end{array}$ & 4 lata \\
\hline Specjalista & $\begin{array}{l}\text { szkoła wyższa } \\
\text { (III-IV poz. akred.); }\end{array}$ & $\begin{array}{c}\text { po uzyskaniu tytułu } \\
\text { zawodowego } \\
\text { licencjata }\end{array}$ & 1 rok \\
\hline Magister & $\begin{array}{l}\text { szkoła wyższa } \\
\text { (IV poz. akred.); }\end{array}$ & $\begin{array}{c}\text { po uzyskaniu tytułu } \\
\text { zawodowego } \\
\text { licencjata }\end{array}$ & $1-1,5$ roku \\
\hline Magister & $\begin{array}{l}\text { szkoła wyższa } \\
\text { (IV poz. akred.) }\end{array}$ & $\begin{array}{c}\text { po uzyskaniu tytułu } \\
\text { zawodowego } \\
\text { specjalisty }\end{array}$ & $1 \mathrm{rok}$ \\
\hline
\end{tabular}

Źródło: (Szkwir 2011: 60)

\footnotetext{
1 Kolegium/Liceum Pedagogiczne to uczelnia (I-II poziom akredytowania), która prowadzi działalność edukacyjną; funkcjonuje według dwóch modeli: 1) jako wydział uczelni wyższej; 2) jako uczelnia samodzielna.

2 Akademia, Instytut - uczelnia wyższa (III poziom akredytowania) techniczna, pedagogiczna, teologiczna, medyczna, ekonomiczna, prawna, farmaceutyczna, rolnicza, artystyczna); prowadzi innowacyjną działalność edukacyjną.

3 Uniwersytet - to wyższa uczelnia interdyscyplinarna (IV poziom akredytowania) (klasyczna, techniczna) lub (pedagogiczna, sportowa, humanitarna, teologiczna, medyczna, ekonomiczna, prawna, farmaceutyczna, rolnicza, artystyczna); realizuje innowacyjną działalność edukacyjną na różnych poziomach szkolnictwa wyższego.
} 
Czwarty etap (trójstopniowy) - rok 2014-2017

Czterostopniowe przygotowanie nauczycieli edukacji wczesnoszkolnej zostało zamienione na trójstopniowe: „młodszy specjalista - licencjat - magister”. Priorytetową rolę w zakresie tworzenia systemu kształcenia nauczycieli edukacji wczesnoszkolnej odegrała nowa Ustawa o szkolnictwie wyższym (Zakon Ukrajiny "Pro wyszczu oswitu” 2014), w której zaznaczone zostało, że przygotowanie przyszłych nauczycieli może się odbywać na trzech poziomach: poziom podstawowy (krótki cykl studiów); poziom pierwszy (I stopień studiów); poziom drugi (II stopień studiów). Zakończenie każdego kończy się uzyskaniem odpowiedniego tytułu zawodowego: młodszego licencjata, licencjata oraz magistra.

Modele przygotowania przyszłych nauczycieli edukacji wczesnoszkolnej mogły odbywać się w dwóch formach: w dwóch uczelniach lub na jednej.

Pierwsza forma: Przygotowanie nauczycieli edukacji wczesnoszkolnej do zawodu w dwóch uczelniach.

a) Studia w Kolegium/Liceum Pedagogicznym

Po ukończeniu klasy IX kandydat mógł podjąć studia pedagogiczne składając w Kolegium/Liceum Pedagogicznym egzaminy z dwóch przedmiotów: biologii i języka ukraińskiego. Czas nauki trwał 3 lata i 8 miesięcy i kończył się uzyskaniem tytułu zawodowego młodszego licencjata. Ukończenie tych studiów pozwalało absolwentowi studiów podjąć pracę w zawodzie lub kontynuować naukę na uczelni wyższej.

Kandydat mógł podjąć studia w Kolegium/Liceum Pedagogicznym także po ukończeniu szkoły ogólnodostępnej (klasa XI). Warunkiem przyjęcia na studia były wyniki egzaminu maturalnego z języka ukraińskiego, matematyki, biologii lub historii Ukrainy - do wyboru przez kandydata. Czas nauki trwał 1 rok i 10 miesięcy i kończył się uzyskaniem tytułu zawodowego młodszego licencjata. Ukończenie tych studiów pozwalało absolwentowi podjąć pracę w zawodzie lub kontynuować naukę na uczelni wyższej.

b) Studia na uczelni wyższej

Jak już wyżej zostało zaznaczone, absolwent Kolegium/Liceum Pedagogicznego mając tytuł zawodowy młodszego licencjata, mógł kontynuować studia na uczelni wyższej, rozpoczynając od 3 roku studiów. Studia pierwszego stopnia na uczelni wyższej trwały 4 lata i kończyły się uzyskaniem tytułu zawodowego licencjata. Studia II stopnia trwały 1 rok i 4 miesiące, po czym absolwent uzyskiwał tytuł zawodowy magistra.

Druga forma: Przygotowanie nauczycieli edukacji wczesnoszkolnej do zawodu na jednej uczelni.

a) Studia na uczelni wyższej po ukończeniu szkoły ogólnodostępnej. 
Przygotowanie nauczycieli edukacji wczesnoszkolnej odbywało się na uczelni wyższej: w Akademii, Instytucie oraz na Uniwersytecie. Kandydat po ukończeniu szkoły ogólnodostępnej mógł studiować na uczelni wyższej w celu uzyskania tytułu zawodowego licencjata lub magistra. Kandydat na studia pedagogiczne składał maturę z języka ukraińskiego, biologii lub matematyki oraz historii Ukrainy - do wyboru. Studia pierwszego stopnia trwały 4 lata. Po ukończeniu studiów drugiego stopnia, które trwały 1 rok i 4 miesiące, student uzyskiwał tytuł zawodowy magistra (Tab. 2).

Tabela 2. Przygotowanie do zawodu nauczyciela edukacji wczesnoszkolnej w latach 2014-2017

\begin{tabular}{|c|c|c|c|}
\hline Tytuł zawodowy & $\begin{array}{c}\text { Typ uczelni } \\
\text { (poziom akredytowania) }\end{array}$ & $\begin{array}{l}\text { Typ ukończonej } \\
\text { szkoły (klasy) }\end{array}$ & $\begin{array}{l}\text { Czas trwania } \\
\text { nauki }\end{array}$ \\
\hline Młodszy specjalista & $\begin{array}{l}\text { kolegium/liceum } \\
\text { pedagogiczne } \\
\text { (I-II poz. akred/); }\end{array}$ & $\begin{array}{l}\text { po ukończeniu } \\
\text { klasy IX }\end{array}$ & 3 lata i 8 miesięcy \\
\hline Młodszy specjalista & $\begin{array}{l}\text { kolegium/liceum } \\
\text { pedagogiczne } \\
\text { (I-II poz. akred/); }\end{array}$ & $\begin{array}{c}\text { po ukończeniu szkoły } \\
\text { ogólnodostępnej } \\
\text { (klasa XI) }\end{array}$ & $\begin{array}{l}1 \text { rok i } 10 \\
\text { miesięcy }\end{array}$ \\
\hline Licencjat & $\begin{array}{c}\text { szkoła wyższa } \\
\text { (III-IV poz. akred.): }\end{array}$ & $\begin{array}{l}\text { po ukończeniu } \\
\text { kolegium/liceum } \\
\text { pedagogicznego }\end{array}$ & 2 lata \\
\hline Licencjat & $\begin{array}{c}\text { szkoła wyższa } \\
\text { (III-IV poz. akred.); }\end{array}$ & $\begin{array}{c}\text { po ukończeniu szkoły } \\
\text { ogólnodostępnej } \\
\text { (klasa XI ) }\end{array}$ & 4 lata \\
\hline Magister & $\begin{array}{l}\text { szkoła wyższa } \\
\text { (IV poz. akred.); }\end{array}$ & $\begin{array}{c}\text { po uzyskaniu tytułu } \\
\text { zawodowego } \\
\text { licencjata }\end{array}$ & 1 rok i 4 miesiące \\
\hline
\end{tabular}

Źródło: (Szkwir 2011: 63)

\section{Piaty etap (reformatorski) - rok 2017 po czasy obecne}

W roku 2017/2018 w szkolnictwie ukraińskim odbyły się duże zmiany. Po pierwsze, w 2017 roku tytuł zawodowy specjalista został zniesiony. Po drugie, w 2018 roku został wdrożony projekt „Nowa ukraińska szkoła”. To nowy program rozwoju szkoły ogólnodostępnej, nakierowany na transformację ustrojową systemu szkoły, w tym wydłużenie nauki o rok od jedenastu do dwunastu lat oraz wprowadzenie nowych typów gimnazjów i liceów profilowanych, co stanowi novum w systemie edukacyjnym (Koncepcija „Nowa ukrainska szkola” 2017). 
Zgodnie z Koncepcją „Nowa ukraińska szkoła”, treść przygotowania nauczycieli edukacji wczesnoszkolnej uległa modyfikacji. Wprowadzenie w dniu 10 sierpnia 2018 roku standardu zawodowego „Nauczyciel edukacji wczesnoszkolnej w szkole ogólnodostępnej”, opracowanego przez Ministerstwo Edukacji i Nauki Ukrainy, pociągnęło za sobą zmiany w kształceniu nauczycieli (Stanadart „Wczytel poczattkowych klasiw zakładu zagalnoji serednoji oswity” 2018). Dokument kładł większy nacisk na przygotowanie praktyczne do zawodu, określając minimalną liczbę godzin obowiązkowych praktyk oraz wyraźnie definiując funkcje, niezbędne kompetencje zawodowe, wiedzę oraz umiejętności nauczyciela edukacji wczesnoszkolnej. Szczególną uwagę zwracano na funkcje nauczyciela, w tym na: planowanie i realizację procesu edukacyjnego; zapewnianie i wspieranie procesu rozwoju, szkolenie i edukację uczniów i ich rodzin; tworzenie środowiska edukacyjnego; rozwój zawodowy; prowadzenie badań pedagogicznych; zapewnienie kolegom pomocy merytorycznej w zakresie edukacji, rozwoju i wychowania; uogólnienie własnego doświadczenia pedagogicznego i jego prezentacji społeczności pedagogicznej; ocenę wyników swojej pracy. Każda z funkcji określała zawodowe kompetencje pedagogiczne, wiedzę, umiejętności, które powinien był posiadać przyszły nauczyciel.

Z związku z wprowadzeniem reformy „Nowa ukraińska szkoła” odbyły się zmiany w przygotowaniu nauczycieli edukacji wczesnoszkolnej. Trudno przewidzieć, jak będzie wyglądało przygotowanie nauczycieli edukacji wczesnoszkolnej do zawodu w roku 2027 (zakończą wówczas naukę pierwsi absolwenci gimnazjów) lub w roku 2030 (zakończą wówczas naukę pierwsi absolwenci liceów). Można to przedstawić za pomocą schematu (Tab. 3).

Tabela 3. Przygotowanie nauczycieli edukacji wczesnoszkolnej od 2017 roku do czasu obecnego

\begin{tabular}{|c|c|c|c|}
\hline Gimnazjum & Młodszy licencjat & Licencjat & Magister \\
\hline Liceum & Licencjat & & Magister \\
\hline
\end{tabular}

Źródło: opracowanie własne

Warto dodać, że obecnie w edukacji wczesnoszkolnej oraz w placówkach wychowania pozaszkolnego mogą pracować osoby po ukończeniu krótkiego cyklu nauczania, czyli po zakończeniu Kolegium/Liceum Pedagogicznego, lub z tytułem zawodowym młodszy licencjat. Na Ukrainie nie ma konieczności uzyskania wyższego wykształcenia przez wszystkich nauczycieli. 


\section{Realizacja Programu studiów na kierunku Edukacja wczesnoszkolna na przykładzie Akademii Humanistyczno- -Pedagogicznej w Chmielnickim}

W tej części artykułu chciałabym zaprezentować proces przygotowania do zawodu przyszłych nauczycieli edukacji wczesnoszkolnej na przykładzie Akademii Humanistyczno-Pedagogicznej (dalej - Akademia) w Chmielnickim w roku akademickim 2019/2020 (Chmelnycka Academia Humanitarno-Pedagogiczna 2020). Przyszły nauczyciel kierunku Edukacja wczesnoszkolna ma do wyboru dwie formy przygotowania do zawodu:

Pierwsza forma przygotowania nauczycieli do zawodu: po ukończeniu klasy IX

Kandydat na studia po ukończeniu klasy IX może wstąpić do Kolegium Pedagogicznego, które jest w strukturze Akademii. Po jego ukończeniu absolwent uzyskuje tytuł zawodowy młodszego licencjata i specjalność nauczycielską: Nauczyciel edukacji wczesnoszkolnej ze specjalnością dodatkową: „Nauczyciel języka angielskiego/ niemieckiego”, „Nauczyciel informatyki klas początkowych”; „Nauczyciel WF klas początkowych”; „Nauczyciel plastyki klas początkowych”. Student jest obowiązany uzyskać 228,5 punktów ECTS. Czas nauki trwa 3 lata i 10 miesięcy.

Po ukończeniu Kolegium Pedagogicznego i mając tytuł zawodowy młodszego licencjata, kandydat może kontynuować studia w Akademii. Rozpoczyna studia od III roku studiów.

Po zakończeniu studiów pierwszego stopnia student uzyskuje tytuł zawodowy licencjata. W celu uzyskania dyplomu studiów pierwszego stopnia student jest obowiązany uzyskać 180,5 punktów ECTS. Nauka trwa 1 rok i 10 miesięcy. Osoba z tytułem zawodowym licencjata może kontynuować studia drugiego stopnia w celu uzyskania tytułu zawodowego magistra. Student jest obowiązany uzyskać 955 punktów ECTS. Nauka trwa 1 rok i 6 miesięcy.

Druga forma przygotowania nauczycieli do zawodu: po ukończeniu szkoły ogólnodostępnej

Po ukończeniu szkoły ogólnodostępnej kandydat może podjąć studia w Akademii w celu uzyskania tytułu zawodowego licencjata. Student jest obowiązany uzyskać 240 punktów ECTS. Studia pierwszego stopnia trwają 3 lata i 10 miesięcy. Studia drugiego stopnia kończą się uzyskaniem tytułu zawodowego magister. Student jest obowiązany uzyskać 955 punktów ECTS. Nauka trwa 1 rok i 6 miesięcy. Realizacja programów studiów na kierunku Edukacja wczesnoszkolna pierwszego stopnia 
prowadzonych w formie studiów stacjonarnych w Akademii Humanistyczno-Pedagogicznej w Chmielnickim przywiduje:

I rok studiów:

zapoznanie studentów z wiedzą na temat przyszłego zawodu nauczyciela;

- nabywanie przez studentów wiedzy psychologicznej i pedagogicznej;

uświadomienie studentom ważności roli społecznej nauczyciela;

- rozwijanie u studentów pozytywnego stosunku do zawodu nauczyciela;

- nabywanie przez studentów kompetencji komunikatywnych, informacyjno-analitycznych, badawczo-praktycznych.

$\mathrm{Na}$ II roku studiów odbywa się:

- pogłębione zapoznanie studentów z przedmiotami psychologicznymi i pedagogicznymi;

- włączanie studentów w badania pedagogiczne, w ramach których odbywa się kształtowanie umiejętności zawodowych;

- nabywanie głębokiej wiedzy psychologicznej, filologicznej, przyrodniczej, technicznej oraz artystycznej.

III rok studiów charakteryzuje się:

pogłębieniem humanistycznego światopoglądu studentów;

opanowaniem przez studentów elementów kreatywnego rozwiązywania problemów;

opanowaniem przez studentów podstaw etyki zawodowej;

- nabywaniem umiejętności systematycznej pracy;

- nabywaniem kompetencji zawodowych i komunikacyjnych.

IV rok studiów przeznaczony jest na:

nabywanie przez studentów wiedzy teoretycznej i zawodowej,

- nabywanie przez studentów umiejętności praktycznych i kompetencji zawodowych;

- kształtowanie u studentów umiejętności rozwiązywania problemów w różnych sytuacjach pedagogicznych, w których przyszły nauczyciel może wykazać się wysokim poziomem wiedzy teoretycznej z pedagogiki, psychologii oraz indywidualnych metod nauczania.

Lista kompetencji zawodowych uwzględnia zarówno wymogi pracodawców, jak i oczekiwania samych studentów oraz łączy tradycyjne i innowacyjne podejście przygotowania nauczycieli do zawodu (Binycka 2018). 
W programie studiów na kierunku edukacja wczesnoszkolna pierwszego stopnia, prowadzonych $\mathrm{w}$ formie studiów stacjonarnych, wyodrębnia się aspekty:

- kulturowy (rozumienie stanu i tendencji rozwoju cywilizacji);

- psychologiczny (nabywanie umiejętności do interakcji z uczniami, zrozumienie ich osobowości);

metodyczny (opanowanie metod, które pozwolą uczyć się lepiej i szybciej przyswajać wiedzę);

- przedmiotowy (doskonała znajomość przedmiotu) (Chmelnycka Academia Humanitarno-Pedagogiczna 2020).

W trakcie studiów przyszli nauczyciele uczą się wybierać tematy interesujące dla uczniów, opanowują nowe strategie w nauczaniu i odpowiednie metody nauczania. Szczególną uwagę w programie studiów zwraca się na pedagogikę zabawy oraz wprowadzenie elementów metody projektów.

\section{Podsumowanie}

Wobec przyspieszenia procesów globalizacyjno-integracyjnych i przemian demokratycznych staje się aktualne zadanie podniesienia jakości kształcenia w szkole ogólnodostępnej. Podstawowe założenia reformowania systemu edukacji na Ukrainie zostały zaprezentowane w Koncepcji „Nowa ukraińska szkoła”. Jednym z zadań priorytetowych jest przede wszystkim modernizacja edukacji wczesnoszkolnej. Od jakości kształcenia uczniów na etapie początkowym, czyli w klasach I-III, będzie zależeć sukces uczniów na następnych szczeblach nauki (w gimnazjum i liceum), wybór zawodu, rozwój kariery oraz konkurencyjność na rynku pracy. W związku z powyższym staje się oczywistym stopniowe reformowanie systemu przygotowania nauczycieli edukacji wczesnoszkolnej do zawodu, ponieważ od tego zależy skuteczność wdrożenia nowego paradygmatu edukacji, opartego na podejściu indywidualnym do ucznia, pedagogice współpracy, demokratyzacji i indywidualizacji procesu kształcenia. Zgodnie z Koncepcją, nauczyciele edukacji wczesnoszkolnej powinni kształtować w dzieciach kompetencje kluczowe, niezbędne człowiekowi w XXI wieku.

Obecnie na Ukrainie istnieją dwie formy przygotowania nauczycieli do zawodu: pierwsza: po ukończeniu klasy IX - przygotowanie trzystopniowe (młodszy licencjat, licencjat i magister). Przyszli nauczyciele podejmują studia w Kolegium/Liceum Pedagogicznym oraz mogą kontynuować naukę w Instytutach Pedagogicznych, Akademiach lub na Uniwersytetach. Druga forma - po ukończeniu klasy XI, czyli po ukończeniu szkoły ogólnodostępnej - zakłada przygotowanie dwustopniowe (licencjat, magister). Przyszli nauczyciele studiują w Instytutach, Akademiach lub na Uniwersytetach. 
Biorąc pod uwagę zapis Ustawy o szkolnictwie wyższym, że warunkiem uzyskania tytułu zawodowego „młodszego licencjata” i „licencjata” jest ukończenie szkoły ogólnodostępnej, przygotowanie do zawodu będzie się odbywać na dwóch poziomach studiów: licencjackiego i magisterskiego. To z kolei doprowadzi do istotnych zmian w strukturze typów uczelni pedagogicznych, warunkach rekrutacji studentów; w treści planów nauki, metod i form przygotowania przyszłych nauczycieli.

\section{Bibliografia}

Binycka K. (2018). Pidgotowka majbutnich uczyteliw poczatkowoji oswity u krainach Schidnoji Jewropy: teoria i praktyka, Chmelnyćkyj; FOP Cupak A.A.

Budak W. (2002). Jakist pedagogicznoi oswity - majbutnje Ukrajiny. „Technologii neperewnoji oswity: problemy, doswid, perspektywy rozwytku: zbirnyk statej do tradycijnoji IV Wseukrainskoji naukowo-praktycznoji konferencji", Mykolajiw: Wydawnictwo MFNaUKMA, s. 3-6.

Busel W. (2004). Wielki stownik języka ukraińskiego, Irpin: WTF „Perun”.

Chmelnycka Academia Humanitarno-Pedagogiczna (2020), http://kgpa.km.ua/blog [dostęp: 2.02.2020].

Zakon Ukrajiny „Pro wyszczu oswitu” (2014), https://zakon.rada.gov.ua/laws/show/1556-18\#Text [dostęp: 21.12.2020].

Chomicz L. (1999). Systema psychologo-pedagogicznoji pidgotowky wczytela poczatkowych klasiw: monografia, Kyjiw: Magistr.

Ewtuch M. (2005). Naukowo-organizacijni problemy stupenewoji profesijnoji pidgotowky pedagogiw, „Wisnyk Lwiwskogo Uniwersytetu” 19, s. 3-8.

Ziaziun I. (2000). Intelektualno tworczyj rozwytok osobystosti $w$ umowach nepererwnoji oswity. Nepererwna profesijna oswita: problemy, poszuky, perspektywy: monografia, Kyjiw: Wipol.

Kairow I., Pietrow F. (1964-1968). Pedagogiczeskaja encyklopedia, Moskwa: Cowetskaja encyklopedia, T. 3.

Koncepcija rozwytku pedagogicznoji oswity (2018), https://mon.gov.ua/ua/npa/pro-zatverdzhennya-koncepciyi-rozvitku-pedagogichnoyi-osviti [dostęp: 2.12.2020].

Koncepcija „Nowa ukrainska szkola” (2017), https://mon.gov.ua/ua/tag/nova-ukrainska-shkola [dostęp: 12.12.2020].

Onuszkin W., Ogarew E. (1995). Obrazowanie wzrostych: mezdiscyplinarny slowar terminologii, Sankt-Peterburg-Woroneż: Izdatelstwo Instituta obrazowania wzrosłych RAO.

Oswita w cyfrach: jak zminylas kilkist szkil za ostanni roky (2017), https://nus.org.ua/news/ osvita-v-tsyfrah-yak-zminylas-kilkist-shkil-za-ostanni-roky/ [dostęp: 21.12.2020].

Ożegów S., Szwedowa N. (1990). Stownik języka rosyjskiego, Moskwa: Ruskij jazyk.

Piwdennoukrajnsky nawczalny kompleks „Pedagog”, https://pdpu.edu.ua/en/informatsiya-2/vsi-kategoriji/288-universitet/spivpratsia-z-robotodavtsiamy/4238-dogovori-pro-spivpratsyu-2020.html [dostęp: 11.12.2020]. 
Pro Nacionalnu strategiju rozwytku oswity w Ukrajini na period do 2021 roku (2013), https://zakon.rada.gov.ua/laws/show/344/2013\#Text [dostęp: 21.12.2020].

Semiczenko W. (1992). Koncepcja celostnosci i eje realizacja w professionalnoj podgotowke buduszczich uczitelej (psichologo-pedagogiczeskij aspekt): disertacja doktora psychologiczeskich nauk, KGPI im. Dragomanowa.

Stanadart „Wczytel poczatkowych klasiw zaktadu zagalnoji serednoji oswity” (2018), https:// mon.gov.ua/ua/news/yaki-kompetentnosti-znannya-ta-vminnya-povinen-mati-vchitel-pochatkovih-klasiv-zatverdzheno-pershij-v-ukrayini-profesijnij-standart [dostęp: 21.11.2020].

Skilky wczyteliw narachuwaly mynulogo nawczalnogo roku? (2017), https://www. pedrada.com.ua/article/1315-sklki-vchitelv-narahuvali-minulogo-navchalnogoroku?from=PW_Auth\&ustp=W [dostęp: 10.12.2020].

Sysojewa S., Sokołowa I. (2010). Problemy nepererwnoji profesijnoji oswity: tezarus naukowogo doslidzennja, Kyjiw: WDEKMO.

Szkwir O. (2011). Doswid stupenewoji pidgotowky majbutnich uczyteliw początkowych klasiw. „Pedagogiczny dyskurs: zbirnyk naukowych prac” 9, s. 367-371.

Szkwir O. (2018). Stupenewa pidgotowka majbutnich uczyteliw pocztakowoji szkoly do prowedennja pedagogicznych doslidżen, Żytomyr: Wydawnictwo ŻDU im. I. Franka.

Uszyński K., (1983). Projekt uczycielskoji seminariji. Wybrani pedagogiczni twory w 2 tomach, Kyjiw: Radjańska szkola, T. 2, s. 31-56.

Winnickij derżawnyj pedagogiczny uniwersytet im. Mychajla Kocubynskogo (2020), https:// vspu.edu.ua/faculty/pochat/pochat_kafmetod/pochat_abit.php [dostęp: 10. 12.2020]. Zakon Ukrajiny "Pro oswitu” (1991), https://zakon.rada.gov.ua/laws/show/1144-12\#Text [dostęp: 19.12.2020].

\section{ADRES DO KORESPONDENCJI}

Olena Bocharova

Uniwersytet Pedagogiczny w Krakowie im. Komisji Edukacji Narodowej e-mail: olena.bocharova@up.krakow.pl 